Social Networking of Owner-Managers in Small Accommodation in Malaysia: Implications for HRD

\title{
Victoria Jonathan*
}

Universiti Malaysia Sarawak, 94300 Kota Samarahan, Sarawak, Malaysia

\begin{abstract}
Small accommodation providers are challenged to grow their business due to their limited resources. Although social networking is suggested to assist organization growth, few studies have focused on how owner-managers in the Malaysian hospitality industry network and the value they attach to it. This paper presents findings of 10 in-depth interviews of social networking motivation and barrier of ownermanagers of small accommodation in Kuching, Malaysia. The findings show that the owner-managers were motivated by the perceived organizational and personal benefits of networking with others. However, issues such as social competence and business concerns were identified as barriers that may limit their participation in networking. To overcome these issues, it is suggested that educators, policymakers, and trade associations work together with the owner-managers to address their specific development and resource needs.
\end{abstract}

Keywords: Social networking; small firm; SME; entrepreneur; Malaysia

\section{INTRODUCTION}

The tourism and hospitality industry is an important growth area for Malaysia, with emphasis as one of the National Key Economic Areas for Malaysia under the Economic Transformation Program and total earnings increasing from $\$ 4.9$

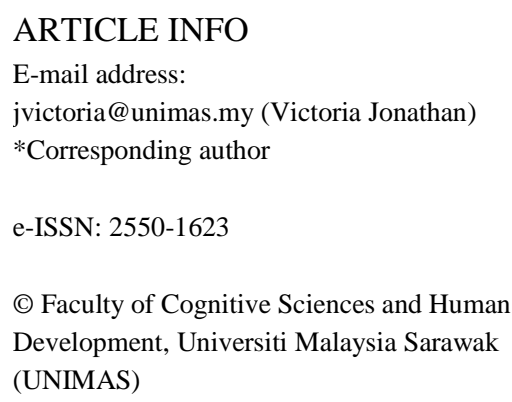

billion in 2003 to $\$ 15.2$ billion in 2013 (Tourism Malaysia, 2015). This industry includes services in accommodation, shopping, and recreational activities. In Malaysia, small medium enterprises (SMEs) in the services sector are defined as those with sales turnover that does not exceed \$6.5 million or does not exceed 75 employees (SME Corporation Malaysia, 2013).

While there have been studies in tourism and small hotels (Abdullah, Ishak \& Bustaman, 2011; Jaafar, Toh, \& M.Sukaron, 2011; Md. Salleh, Abdul Hamid, Hashim \& Omain, 2010; Chan \& 
Quah, 2008), few research has focused on the value of networking relationships for small firm performance in the Malaysian context (Farinda, Kamarulzaman, Abdullah, \& Ahmad, 2009). Small businesses are limited in terms of resources, which may lead to limited growth. However, small businesses may turn to their social networks to improve their business and overcome resource constraints (Jack et al., 2004). Recently, Latip (2012) studied networking relationships among entrepreneurs in Malaysia. Although her study provided generalizability to other SMEs, the nature and challenges of small hotels in Malaysia are different from other industries and context dependent. Furthermore, several scholars also suggest using a qualitative approach to research this area (Jack, 2010; Wiklund, Patzelt, \& Shepherd, 2009), to increase contextual understanding of the phenomenon in question (Borch \& Arthur, 1995). Therefore, this study used a qualitative case study approach to understand networking relationships of ownermanagers in small accommodation. From a HRD perspective, networking is an important competence for entrepreneurs to establish, develop and sustain longterm networking relationships.

Therefore, the purpose of this qualitative case study is to examine social networking participation of owner-managers of small accommodation in the Malaysian tourism SMEs. Specifically, this inquiry answers the questions: What motivates these owner-managers to participate in networking activities? What are the barriers to their participation in networking activities?
This study contributes to the understanding of a currently limited, contextdependent and crucial sector in Malaysia. This study contributes to the entrepreneurship and tourism SME literature by applying knowledge from entrepreneurship, and social capital theory. It adds to the body of knowledge of small accommodation owner-managers about their social networking participation, motivations and barriers. Policymakers and entrepreneurship educators may also identify networking competency, infrastructure and programs that could facilitate networking success for SMEs. The article starts by briefly reviewing small business networking literature followed by the methodology used for the study. This is followed by a description of the findings, discussion, implications of the study and a conclusion.

\section{LITERATURE REVIEW}

Networking is a useful strategy for small firm entrepreneurs. Successful networking allows entrepreneurs to expand their businesses by providing opportunity to access a diversity of knowledge and resources (Zhou, Wu \& Lo, 2007), opportunities for competition (Wetsterlund, Rajala, \& Leminen, 2008), and internalization and innovation (Chetty \& Stangl, 2010; Loane \& Bell, 2006). The importance of networking relationships in entrepreneurship is evident from the literature (i.e. Bratkovic, Antoncic, \& DeNoble, 2012; Casson \& Giusta, 2007; Hoang \& Antoncic, 2003). In one quantitative study involving 569 farmer market vendors in the U.S., Hinrichs et al. (2014) discovered the vendors that net- 
worked with customers seemed to be more innovative in their marketing strategies, compared to those who networked with just other vendors. Furthermore, networking with both customers and fellow vendors provided an advantage to reach other markets beyond the farmers' market. In addition, a research by Lans et al. (2008) with 25 small greenhouse horticulture business owners in the Netherlands, seemed to suggest that external interaction was crucial to the entrepreneurial learning process. The entrepreneurs' interaction with traders, consumers and suppliers facilitated the entrepreneurs' learning of the business process (Lans et al., 2008).

Although the literature seemed to show the benefits of participating in networking relationships, not all entrepreneurs were able to actively engage in networking. Due to the nature of a small firm, the entrepreneur is normally responsible for all its operational activities, leaving less time for strategic efforts. A study by Frazier and Niehm (2004), found that small retailers with limited time, budget, and different perception of strategic information may search information from more informal but accessible contacts. Trust is also an important element in building and sustaining networking relationships. Without investing sufficient time, it is harder to build trust (Nakamura \& Yorks, 2011) and social capital (Cohen \& Prusak, 2001).

Despite the benefits of social networking highlighted in the extant literature, small firm research shows the need to further inquire into how attributes of social net- works contribute to the success of entrepreneurial process. According to several scholars, there is a pressing need to understand the content of network interactions, the mechanisms and processes within and between networks, and the relationship of entrepreneurial networks to firm growth (Drakopolou-Dodd, Jack, \& Anderson, 2006; Hoang \& Antoncic, 2003). Furthermore, more empirical studies are needed in specific context (i.e. industry, small business, culture) to extend our understanding of network relationships in different settings.

This study applied a social capital theory perspective to understand the establishment, development and management of networking relationships. Social capital theory proposes that a network provides value to its members by allowing them access to social resources that are embedded within the network (Bourdieu, 1986; Seibert et al., 2001). However, social capital is created by trust, mutual obligation, expectations and norms among network members (Gulati, 1995). An individual's level of social capital translates to more benefits derived from the relationships in the network. In the context of firms, social capital theory may explain why some firms are more successful than others because of their connection to other individuals, firms or groups (Burt, 2005; Koka \& Prescott, 2002).

\section{METHODOLOGY}

The objective of the current study was to identify the motivations and challenges of networking relationships among own- 
er-manager of small accommodation in Malaysia. A qualitative case study design was chosen as the approach to inquiry. Case study research is a wellestablished qualitative technique, which emphasizes the rich, real-world context in which the phenomenon occurs. Andrade (2009) noted that case studies are conducted in natural settings, and allow researchers to grasp a holistic understanding of a phenomenon under investigation. Another distinct feature of case study is evidence from multiple sources (e.g. interviews, observation, documentation, audio-visual) because findings are likely to be more accurate if they were based on several different sources of information (Yin, 2009; Creswell, 2007). Therefore, a case study methodology provided the opportunity to understand networking relationships of individual entrepreneurs as well as across entrepreneurs in the tourism and hospitality industry.

The study location was in Kuching, a city in the state of Sarawak, Malaysia. In this study, purposive sampling was used as this approach assisted in identifying study participants who could provide most relevant information on relationships between participants and their context (Maxwell, 2013). Ten ownermanagers of small hospitality businesses were interviewed for the study (Table 1). Sample selection criteria was based on those with at least two years' experience, played an active role in running the business, local independently owned hotels and has less than 75 employees. The participants were selected from various websites related to tourism accommodation and hospitality services such as SME Malaysia Directory 2015/2016, Sarawak Tourism Board, Sarawak Tourism Federation, Malaysia Association of Hotels and Malaysia Budget Hotel Association. The number of participants were based on saturation of information. Data saturation occurs when there is no new relevant data discovered in a category (Rudestam \& Newton, 2007; Merriam, 2009), when one is no longer learning anything new (Seidman, 1998), or when further coding is no longer feasible (Guest, Bunce, \& Johnson, 2006).

Data collection also included interviews

Table 1: Demographics of Study Participants

\begin{tabular}{cllccl}
\hline Participant & Gender & Age & $\begin{array}{c}\text { Years with } \\
\text { current organ- } \\
\text { ization }\end{array}$ & $\begin{array}{c}\text { Years of experi- } \\
\text { ence in hospital- } \\
\text { ity industry }\end{array}$ & Role \\
\hline P1 & Male & Early 40s & 3 & 10 & Manager \\
\hline P2 & Female & Mid 30s & 7 & 7 & Owner-Manager \\
\hline P3 & Female & Early 30s & 6 & 6 & Manager \\
\hline P4 & Male & Late 40s & 12 & 12 & Owner-Manager \\
\hline P5 & Female & Early 40s & 7 & 7 & Owner-Manager \\
\hline P6 & Male & Late 50s & 10 & 40 & Manager \\
\hline P7 & Male & Late 50s & 5 & 40 & Manager \\
\hline P8 & Female & Mid 30s & 4 & 7 & Owner-Manager \\
\hline P9 & Male & Late 50s & 16 & 30 & Manager \\
\hline P10 & Male & Late 50s & 2 & 40 & Manager \\
\hline
\end{tabular}


with representatives of a hotel association, an observation study and document analysis. The use of multiple sources of data provided the researcher with a richer set of data (Yin, 2009; Lincoln \& Guba, 1985) and afforded the researcher some level of protection against biases of a single method, single source or single investigator (Patton, 1999). Semistructured interviews were conducted face-to-face either at the interviewees' offices or at an agreed alternative venue. Interviews were conducted in English and local dialects. Each interview session lasted between 40-90 minutes, audio-recorded and transcribed verbatim.

The primary method for analyzing data was content analysis. The transcribed data were uploaded into NVivo11 to assist in data analysis. A combination of descriptive, process, in vivo and attribute coding methods were used to code. Ac- cording to Saldana (2016), a code is a "word or phrase that symbolically assigns a summative, salient, essencecapturing, and/or evocative attribute for a portion of language-based or visual data" (p.4). The coding process enabled the researcher to organize and group similar codes into categories. The researcher preceded to code and categorize all transcripts, observation notes and documents. During this process, the codes and categories were constantly added and revised until the analysis has reached saturation.

\section{FINDINGS}

The majority of participants interviewed were managers of the small accommodation business $(60 \%)$ while the remainder were operated by the owner-managers. All of them have at least six years' experience in the hospitality industry. Their

Table 2: Factors that Motivate Participation of Owner-Managers in Networking Activities

\begin{tabular}{|c|c|c|}
\hline Factors & Description & Example of Quotes \\
\hline $\begin{array}{l}\text { Access to expert } \\
\text { advice }\end{array}$ & $\begin{array}{l}\text { Some participants felt that their participa- } \\
\text { tion in the professional association helped } \\
\text { them to understand new regulations or } \\
\text { procedures. Since the professional associ- } \\
\text { ation's membership consisted of older } \\
\text { and newer members, the newer estab- } \\
\text { lishments could get advice from the more } \\
\text { established and experienced members. } \\
\text { Some participants also sought expert } \\
\text { advice from friends in similar industries. }\end{array}$ & $\begin{array}{l}\text { "You join the association and } \\
\text { then they uhm... will be able to } \\
\text { advise on regulations, new legis- } \\
\text { lations...it's very important ...." } \\
\text { (P2) } \\
\text { "For those hotel, that are new } \\
\text { hotel you know, they are not } \\
\text {...competent yet, they don't } \\
\text { know how to handle this. So, we } \\
\text { will guide them how you } \\
\text { know..." (P6) }\end{array}$ \\
\hline $\begin{array}{l}\text { Access to joint } \\
\text { problem solving } \\
\text { and assistance }\end{array}$ & $\begin{array}{l}\text { Participants described they could collec- } \\
\text { tively solve problems affecting their } \\
\text { businesses. }\end{array}$ & $\begin{array}{l}\text { "Because that is where we share } \\
\text { issues, say for example, there are } \\
\text { issues that affecting us and then } \\
\text { uh...we can just be open... open } \\
\text { to solve problems uh...with one } \\
\text { another...You know sharing of } \\
\text { issues at the same time how to } \\
\text { handle it lah." (P9) }\end{array}$ \\
\hline
\end{tabular}




\begin{tabular}{|c|c|c|}
\hline $\begin{array}{l}\text { Opportunity to } \\
\text { learn from others }\end{array}$ & $\begin{array}{l}\text { Less experienced entrepreneurs and } \\
\text { managers felt that their connections } \\
\text { helped them to learn the ropes of the } \\
\text { business through giving ideas, opinions } \\
\text { and feedback. }\end{array}$ & $\begin{array}{l}\text { "I guess my hotel managers, you } \\
\text { know, they are very experi- } \\
\text { enced. Actually., my hotel man- } \\
\text { ager and finance manager have } \\
\text { been in the hotel industry for } \\
\text { many, many years. I guess the } \\
\text { best way to learn is from them." } \\
\text { (P3) }\end{array}$ \\
\hline $\begin{array}{l}\text { Familiarity with } \\
\text { contacts }\end{array}$ & $\begin{array}{l}\text { The entrepreneurs or managers were } \\
\text { more motivated to network when those } \\
\text { they connected with were those they were } \\
\text { familiar with, including those from simi- } \\
\text { lar backgrounds. For example, the more } \\
\text { experienced or well-established entrepre- } \\
\text { neurs or managers tend to work with } \\
\text { those who they have known a long time } \\
\text { from the industry. }\end{array}$ & $\begin{array}{l}\text { "We have friends here and there. } \\
\text { In the same industry. You see } \\
\text { like uh...me I have a few gen- } \\
\text { eral manager friends from Sin- } \\
\text { gapore, KL, Indonesia, Bangkok } \\
\text { and this kind of thing. I network } \\
\text { with them and get some ideas } \\
\text { from them, through WhatsApp } \\
\text { mostly." (P7) }\end{array}$ \\
\hline
\end{tabular}

ages range from mid $30 \mathrm{~s}$ to late $50 \mathrm{~s}$. There were four female and six male participants.

The data showed that participants identified various types of network that they were a part of. These contacts were divided into two categories: internal (e.g. family members, owners, friends, staff) and external networks (e.g. travel agents, suppliers, professional associations). Each owner-manager maintained several internal and external networks simultaneously. The networks they maintained depended on the business orientation, including current and future business needs. Only four participants admitted to not belonging to any trade association or accommodation-related association while the rest were members.

The owner-managers of small accommodation indicated that there were various factors that contributed to their participation in networking activities. Table 2 summarizes the factors that motivate their participation in networking activities, including some example of quotes.
Networking activities require the individual to be proactive in seeking out contacts and building different networks. Although entrepreneurs and managers may be motivated to network with others, there were also barriers that limited their participation. Table 3 summarizes the barriers to participation of ownermanagers in networking activities including example of quotes.

\section{DISCUSSION}

Generally, entrepreneurs require some degree of social interaction with internal or external contacts, more so in a service-oriented business such as the tourism and hospitality sector. This study found owner-managers of small accommodation businesses participated in social networking to a certain extent. They maintained two types of network ties: internal and external. Although each owner-manager maintained several internal and external networks simultaneously, the networking process and frequency of interaction they maintained were different depending on current and 
Table 3: Barriers to Participation of Owner-Managers in Networking Activities

\begin{tabular}{|c|c|c|}
\hline Factors & Description & Example of Quotes \\
\hline $\begin{array}{l}\text { Social and commu- } \\
\text { nication skills }\end{array}$ & $\begin{array}{l}\text { Networking is a social engagement, there- } \\
\text { fore, require a full range of physical and } \\
\text { emotional behaviors from the individual. } \\
\text { Some of the participants highlighted lack } \\
\text { of social skills as one of the obstacles in } \\
\text { establishing and maintaining networking } \\
\text { relationships with their contacts. Since } \\
\text { networking required social contact, the } \\
\text { ability to communicate and interact with } \\
\text { others was crucial. Participants lacked } \\
\text { adaptability to build rapport and concerned } \\
\text { about interacting with customers whose } \\
\text { professional backgrounds were diverse. }\end{array}$ & $\begin{array}{l}\text { "How do you do networking? } \\
\text { Over coffee? Over drinks? } \\
\text { Over clubbing? Karaoke? It's } \\
\text { different, I don't do all of this } \\
\text { things. You need to be sober } \\
\text { to network [laughs], to talk to } \\
\text { people ... It gets a bit diffi- } \\
\text { cult if you turn them down } \\
\text { [laughs]" (P2) }\end{array}$ \\
\hline Technology skills & $\begin{array}{l}\text { Although technology is gaining im- } \\
\text { portance as an alternative platform for } \\
\text { entrepreneurs and managers to promote } \\
\text { their products and connect with others, it } \\
\text { also posed a challenge to some of the } \\
\text { entrepreneurs and managers since it in- } \\
\text { volved IT knowledge and skills to navi- } \\
\text { gate. Moreover, using social media re- } \\
\text { quired the ability to interact with a differ- } \\
\text { ent type of customer base and to be able to } \\
\text { manage feedback. Some participants de- } \\
\text { scribed their adversity in dealing with } \\
\text { social media to network with customers } \\
\text { and counterparts. }\end{array}$ & $\begin{array}{l}\text { "Ya, I'm in Instagram but } \\
\text { you know lah... I'm not so } \\
\text { active. I'm not very good } \\
\text { with technology, my children } \\
\text { help me with it." (P6) }\end{array}$ \\
\hline $\begin{array}{l}\text { Concerns about } \\
\text { privacy and com- } \\
\text { mercial secrets }\end{array}$ & $\begin{array}{l}\text { Competition exist among small hotels and } \\
\text { between small hotels and other hospitality } \\
\text { provider. There were more hospitality } \\
\text { providers and less people looking for } \\
\text { accommodation. There were concerns that } \\
\text { travelers were also becoming more dis- } \\
\text { cerning regarding their accommodation. } \\
\text { The owner-managers felt that sharing their } \\
\text { knowledge with others may lead to compe- } \\
\text { tition in an already saturated market. }\end{array}$ & $\begin{array}{l}\text { "... to share our secrets, and } \\
\text { our trade secrets, and our so- } \\
\text { called essence to success for } \\
\text { our businesses. But why } \\
\text { should we share that, you } \\
\text { know? At the end of the day, } \\
\text { the market is already compet- } \\
\text { itive enough. Why are we } \\
\text { giving up our knowledge, our } \\
\text { hard-earned knowledge from } \\
\text { experience you know, } \\
\text { wrong-starts a lot of the time } \\
\text { and rectifying it and spend- } \\
\text { ing money in investing learn- } \\
\text { ing, only to actually create } \\
\text { more competition for us..." } \\
\text { (P4) }\end{array}$ \\
\hline $\begin{array}{l}\text { Activities not rele- } \\
\text { vant to business } \\
\text { needs }\end{array}$ & $\begin{array}{l}\text { Although the entrepreneurs and managers } \\
\text { may generally have a positive perception } \\
\text { of networking, they may not participate } \\
\text { due to association activities that did not } \\
\text { meet their needs. Some participants were } \\
\text { reluctant to join conferences or similar } \\
\text { networking events because they did not } \\
\text { cater to the needs of small hospitality } \\
\text { providers. }\end{array}$ & $\begin{array}{l}\text { "When you talk about webi- } \\
\text { nar, conferences and all } \\
\text { that... a lot of them are tai- } \\
\text { lored to big hotels, really, } \\
\text { really loads worth of tourism } \\
\text { volume coming through, and } \\
\ldots \text { and we find that it doesn't } \\
\text { represent us and we don't } \\
\text { take a lot out of it." (P5) }\end{array}$ \\
\hline
\end{tabular}

future business needs. There was also evidence that owner-managers were gradually diversifying their networking approaches to include the Internet and 
social media. The literature also highlights the increasing importance of technology-enabled social networking for entrepreneurs and managers. Due to advancement in technology, more businesses could actively participate in social networking and therefore, increase their connections for personal and professional benefits (Elmore, 2009; Knouse \& Webb, 2001; Leader-Chivee \& Cowan, 2008).

These results of the study underline the motivations and barriers for small accommodation owner-managers to participate in networking activities. Generally, the owner-managers perceived social networking positively and these motivated their participation especially in trade networks. Motivators identified such as access to expert advice, access to joint problem solving and assistance, opportunity to learn from others and familiarity with contacts echo with previous work in this area (Gabbay \& Leenders, 2001; Ahmad, 2005; Lockett, Jack \& Larty, 2012). Most new small accommodation owner-managers lacked related experience and information, therefore, networking would be valuable for them (Martinez \& Aldrich, 2011). Furthermore, connecting with a professional hotel association and other trade networks improves learning while saving time and resources (Miller \& Besser, 2005; Lans et al., 2008).

Although the owner-managers may be motivated to network with others, there were also barriers that limited their participation: social and communication skills, technology skills, concerns about commercial secrets and association activities that were not relevant to small accommodation needs. Social networking requires the owner-managers to build, manage and maintain relationships. As such social and communication skills are important drivers of successful social networking relationships. Some scholars are in consensus that social competency leads to improved business performance (Lans et al., 2016; Meng \& Elliot, 2008; Baron \& Markman, 2000). The growing use of social media and Internet may challenge owner-managers if they lack the know-how, not only to network with contacts but to market their products and services. Some scholars found that entrepreneurs of small firms are limited with their time and resources (Frazier \& Niehm, 2004; Curran et al., 1993). Therefore, participation in trade associations may not be priority especially if the perceived relevance is minimal.

\section{IMPLICATIONS}

Social competency is suggested to be important in social networking and ultimately the performance of small hotels. Currently training and development of entrepreneurs emphasizes on reducing skills gap (Lans et al., 2016), however, less emphasis is placed on soft skills such as social competencies, relationship building skills and negotiation skills. Since social networking is viewed as an entrepreneurial tool (Hoang \& Antoncic, 2003), small accommodation ownermanagers would benefit from training that create and improve on their social competencies and related skills. Similarly, the use of technology is increasingly 
important in businesses for sales and marketing, daily operation or interacting with contacts. As technology may provide more opportunities to network with others, small accommodation ownermanagers would also benefit from training that could improve their technology skills. Educators, trainers and policymakers in entrepreneurship may need to collaborate to identify social and technological competencies to address the social relations aspect of entrepreneurship. In addition, developing social competencies take time. Trade associations act as a network for its members and may be a starting point for developing social networks for its members. More could be done as well to provide activities or development efforts that are more relevant to the needs of small firms and small firm entrepreneurs.

\section{CONCLUSION}

This study contributes to our understanding and extends the literature on networking activities of small firm entrepreneurs in a particular context. Specifically, this study has discovered a few motivations and barriers to social networking of small accommodation ownermanagers. Factors such as access to expert advice, joint problem solving and assistance, opportunity to learn from others and familiarity with contacts motivated their participation in networking. On the contrary, the owner-managers limited their networking activities due to their lack of social and communication skills, lack of technology skills, business privacy concerns and association activities that were not relevant to their needs.
All network actors have a role to play to ensure networking success. Ownermanagers and entrepreneurs need to acquire the necessary social and technological competencies to help them be successful networkers. Educators, trainers and policymakers in entrepreneurship may need to develop efforts to better understand networking interactions, identify networking strategies and provide training to support successful networking.

\section{ACKNOWLEDGEMENTS}

This paper is a part of an ongoing research funded by Universiti Malaysia Sarawak.

\section{REFERENCES}

Abdullah, F.Z., Ishak, N.K., \& Bustaman, F.L. (2012). A case study of small budget chalets at East Coast of Malaysia. International Journal of Business and Social Sciences, 3(1), 275-282.

Ahmad, G. (2005). Small firm ownermanagers' networks in tourism and hospitality. International Journal of Business and Society, 6(2), 37-54.

Andrade, A. D. (2009). Interpretive research aiming at theory building: Adopting and adapting the case study design. The Qualitative Report, 14(1), 42-60.

Baron, R. A., \& Markman, G. D. (2000). Beyond social capital: How social skills can enhance entrepreneurs' success. Academy of Management Executive, 14(1), 106-116. Retrieved from 
http://www.jstor.org/stable/41656 12

Borch, O.J., \& Arthur, M.B. (1995). Strategic networks among small firms: Implications for strategy research methodology. The Journal of Management Studies, 32(4), 419-441.

Bourdieu, P. (1986). The forms of capital. In J.G. Richardson (Ed.), Handbook of theory and research for the sociology of education. Westport, Connecticut: Greenwood Press, Inc.

Bratkovic, T., Antoncic, B., \& DeNoble, A. F. (2012). Relationships between networking, entrepreneurial self-efficacy and firm growth: The case of Slovenian companies. Economic Research, 25(1), 61-71.

Burt, R.S. (2005). Brokerage and closure: An introduction to social capital. Oxford, UK: Oxford University Press.

Casson, M. \& Giusta, M.D. (2007). Entrepreneurship and social capital: Analyzing the impact of social networks on entrepreneurial activity from a rational action perspective. International Small Business Journal 25(3), 220-244.

Chan, J.K.L., \& Quah, W.B. (2008). Key issues on managing small and medium-sized accommodation businesses: An exploratory study. TEAM Journal of Hospitality \& Tourism, 5(1), 13-25.

Chetty, S. K., \& Stangl, L. M. (2010). Internationalization and innovation in a network relationship con- text. European Journal of Marketing, 44(11/12), 1725 - 1743.

Cohen, D. \& Prusak, L. (2001). In good company: How social capital makes organizations work. Boston, Massachusetts: Boston Business School Press.

Cooper, A. C., \& Gascon, F. J. G. (1992). Entrepreneurs, processes of founding, and new firm performance. In D. L. Sexton \& J. D. Kasarda (Eds.), The State of the Art of Entrepreneurship (pp. 301340). Boston: PWS-Kent.

Creswell, J.W. (2007). Qualitative inquiry and research design: Choosing among five approaches $\left(2^{\text {nd }}\right.$ ed.). Thousand Oaks, CA: Sage.

Curran, J., Jarvis, R., Blackburn, R.A., \& Black, S. (1993). Networks and small firms: Constructs, methodological strategies and some findings. International Small Business Journal, 11(2), 13-25.

Drakopoulou-Dodd, S., Jack, S., \& Anderson, A. R. (2006). The mechanisms and processes of entrepreneurial networks: continuity and change. In J. Wiklund, D. Dimov, J. A. Katz \& D. Shepherd (Eds.), Advances in entrepreneurship, firm emergence and growth (Entrepreneurship: frameworks and empirical investigations from forthcoming leaders of European research ed., Vol. 9, pp. 107-145).

Elmore, B. (2009). Social networking strategies. Baylor Business Review, 28(1), 25-26. Retrieved from www.baylor.edu/bbr/Facebook.

Frazier, B.J. \& Niehm, L.S. (2004). Exploring business information net- 
works of small retailers in rural communities. Journal of Developmental Entrepreneurship, 9(1), 23-42.

Gabbay, S.M., \& Leenders, R.A.J. (2000) Social capital of organizations: From social structure to the managemend to social capital. Social Capital of Organizations, 18, 1-20.

Guest, G., Bunce, A. \& Johnson, L. (2006). How many interviews are enough? An experiment with data saturation and variability. Field Methods, 18(1), 59-80. doi: 10.1177/1525822X05279903

Gulati, R. (1995). Does familiarity breed trust? The implications of repeated ties for contractual choice in alliances. The Academy of Management Journal, 38 (1), 85-112

Lincoln, Y.S., \& Guba, E.G. (1985). Naturalistic inquiry. Newbury Park, CA: Sage

Lockett, N., Jack, S., \& Larty, J. (2012). Motivations and challenges of network formation: Entrepreneur and intermediary perspectives. International Small Business Journal, 1-24. Doi: $10.1177 / 0266242612448383$

Hinrichs, C.C., Gillespie, G.W., \& Feenstra, G.W. (2004). Social learning and innovation at retail farmers markets. Rural Sociology, 69(1), 31-58.

Hoang, H., \& Antoncic, B. (2003). Network-based research in entrepreneurship: A critical review. Journal of Business Venturing, 18, 165-187.
http://doi.org/10.1016/S08839026(02)00081-2

Jaafar, M., Toh, K.I., \& M.Sukarno, S.Z. (2011). Problems of small and medium budget hotel operators. World Applied Sciences Journal, 12, 73-79.

Jack, S. L. (2010). Approaches to studying networks: Implications and outcomes. Journal of Business Venturing, 25(1), 120-137. doi: 10.1016/j.jbusvent.2008.10.010

Jack， S.L., Drakopoulou-Dodd, S. \& Anderson, A.R. (2004). Social structures and entrepreneurial networks: The strength of strong ties. The International Journal of Entrepreneurship and Innovation, 5(2), 107-120

Knouse, S., \& Webb, S. (2001). Virtual networks for women and minorities. Career Development International, 6(4), 226-229. doi:10.1108/13620430110397541

Koka, B.R. \& Prescott, J.E. (2002). Strategic alliances as social capital: A multidimensional view. Strategic Management Journal, 23, 795816.

Lans, T., Verhees, F., \& Verstegen, J. (2016). Social competence in small firms: Fostering workplace learning and performance. Human Resource Development Quarterly, 27(3), 321-348. Doi: 10.1002/hrdq. 21254

Lans, T., Biemans, H., Verstegen, J., \& Mulder, M. (2008). The influence of the work environment on entrepreneurial learning of smallbusiness owners. Management Learning, 39(5), 597-613. 
Latip, H., \& Smyrnios, K. (2012). Social capital and entrepreneurship: Building a national entrepreneurial capacity for sustainable development. Paper presented at the 2012 International Conference on Economics, Business and Marketing Management, Singapore (pp.158-162). Singapore: IACSIT Press.

Leader-Chivee, L., \& Cowan, E. (2008). Networking the way to success: Online social networks for workplace and competitive advantage. People and Strategy, 31(4), 40-46. Retrieved from http://www.hrps.org/?page=people strategy

Loane, S., \& Bell, J. (2006). Rapid internationalization among entrepreneurial firms in Australia, Canada, Ireland and New Zealand: An extension to the network approach. International Marketing Review, 23(5), 467-485.

Martinez, M. A., Aldrich, H. E. (2011). Networking strategies for entrepreneurs: Balancing cohesion and diversity. International Journal of Entrepreneurial Behaviour \& Research, 17, 7-38. doi:10.1108/13552551111107499

Maxwell, J.A. (2013). Qualitative research design $\left(3^{\text {rd }} \mathrm{Ed}\right.$.) Thousand Oaks, CA: Sage.

McIntosh, R.W., Goeldner, C.R. \& Ritchie, J.R.B. (1995). Tourism: principles, practices, philosophies ( $7^{\text {th }}$ ed.). New York: Wiley.

Md. Salleh, N.Z., Abdul Hamid, A.B., Hashim, N.H., \& Omain, S.Z. (2010). Issues and challenges in
Malaysian hotel operations. Paper presented at the $3^{\text {rd }}$ Asia-Euro Tourism, Hospitality and Gastronomy conference, Taylor College, Malaysia.

Meng, J., \& Elliott K.M. (2008). Predictors of Relationship Quality for Luxury Restaurants. Journal of Retailing and Consumer Services, 15 (6), 509-515.

Merriam, S.B. (2009). Qualitative research: A guide to design and implementation. San Francisco: Jossey-Bass.

Miller, N. J., \& Besser, T. L. (2005). Exploring decision strategies and evaluations of performance by networked and non-networked small U.S. businesses. Journal of Developmental Entrepreneurship, 10(2), 167-186. Retrieved from http://dx.doi.org/10.1142/S108494 6705000124

Nakamura, Y.T. \& Yorks, L. (2011). The role of reflective practices in building social capital in organizations from an HRD perspective. Human Resource Development Review, 10(3), 222-245.

Patton, M.Q. (1999). Enhancing the quality and credibility of qualitative analysis. HSR: Health Services Research 34(5 Part II), 1189 1208.

Rudestam, K. E., \& Newton, R. R. (2007). Surviving your dissertation: A comprehensive guide to content and process ( $3^{\text {rd }}$ ed.). Los Angeles, CA: Sage Publications.

Saldana, J. (2016). The coding manual for qualitative researchers. Thousand Oaks: Sage. 
Seibert, S.E., Kraimer, M.L. \& Liden, R.C. (2001). A social capital theory of career success. The Academy of Management Journal, 44(2), 219-238. Retrieved from http://www.jstor.org.ezp1.lib.umn. edu/stable/3069452

Seidman, I. (1998). Interviewing as qualitative research (2nd ed.). New York: Teachers College, Columbia University.

SME Corporation Malaysia (2013). Annual Report 2012. Retrieved from http://www.smecorp.gov.my/vn2/n ode/1067

Tourism Malaysia Corporation (2015). Tourist arrivals and receipts to Malaysia. Retrieved from http://corporate.tourism.gov.my/re search.asp?page=facts_figures
Wetsterlund, M., Rajala, R., \& Leminen, S. (2008). SME business models in global competition: A network perspective. International Journal of Globalization and Small Business, 2(3), 342 - 358.

Wiklund, J., Patzelt, H., \& Shepherd, D. (2009). Building an integrative model of small business growth. Small Business Economics, 32(4), 351-374. doi: 10.1007/s11187007-9084-8

Yin, R. K. (2009). Case study research: Design and methods. Thousand Oaks, CA: Sage Publications.

Zhou, Wu, W., \& Luo, X. (2007). Internationalization and the performance of born-global SMEs: The mediating role of social networks. Journal of International Business Studies, 38(4), 673-690. 